AWEJ for Translation \& Literary Studies, Volume 5, Number3. August 2021

DOI: http://dx.doi.org/10.24093/awejtls/vol5no3.11

Pp.151-168

\title{
The Reception of Ernest Hemingway's Works in Albanian Literature and Culture
}

\author{
Lirak Karjagdiu \\ Department of English Language and Literature, Faculty of Philology \\ University of Prishtina, Kosovo \\ Naim Kryeziu \\ Department of German Language and Literature, Faculty of Philology \\ University of Prishtina, Prishtina, Kosovo \\ Corresponding Author: naim.kryeziu@uni-pr.edu \\ Isa Spahiu \\ Department of English Language and Literature, Faculty of Philology \\ University of Tetova, Republic of North Macedonia
}

Received: 6/10/2021

Accepted: 7/19/2021

Published:8/25/2021

\begin{abstract}
The main aim of this paper is to illuminate the positive reception and influence of Hemingway's translated work in the Albanian-speaking world. On the whole, Hemingway's reception in Albanian literature and culture has largely been overlooked and it thus requires more profound attention and consideration. Hence, this paper will attempt to fill up a large vacuum that existed so far in Ernest Hemingway's reception in Albanian literature and culture. "Jeta e re," one of the most reputable literary journals in Kosova, published several journalistic and literary critiques on Hemingway written by various Albanian and international authors throughout the $20^{\text {th }}$ century. Using a critical and comparative literary approach and by referencing these published prefaces, introductions, articles, reviews, etc. mainly by Albanian authors, this paper details and analyzes the research, journalism, and literary criticism published in "Jeta e re" regarding Hemingway's works. The paper concludes that Hemingway's literary works and masterpieces were translated and published frequently and were received with warmth and enthusiasm, leading to Hemingway becoming one of the most admired authors among Albanian readers.
\end{abstract}

Keywords: Albanian language, Ernest Hemingway, culture, literature, reception

Cite as: Karjagdiu, L., Kryeziu, N., \& Spahiu, I. (2021). The Reception of Ernest Hemingway's Works in Albanian Literature and Culture. Arab World English Journal for Translation \& Literary Studies 5 (3) 151-168. DOI: http://dx.doi.org/10.24093/awejtls/vol5no3.11 
AWEJ for Translation \& Literary Studies Volume, 5 Number 3. August 2021

The Reception of Ernest Hemingway's Works in Albanian

Karjagdiu, Kryeziu \& Spahiu

\section{Introduction}

Translation, in general and literary translation, in particular has played a paramount role in the development and enhancement of communication and cooperation of nations and their cultures. In our times, hundreds and thousands of literary works have visited and still visit foreign countries owing to translation. Moreover, thanks to translation of the important and popular literary works and masterpieces of foreign literatures they now belong to all cultured and civilised nations, starting from ancient Greek and Latin literatures till today. Therefore, different nations have managed to advance and enrich their literatures through the translation of the most popular literary works and masterpieces of foreign rich literatures and this way they have integrated their literatures in the world literature. Moreover, literature and culture in general bring nations closer to each other, enable them to get to know each other better, to enhance and advance their mutual cooperation and to develop friendly relations much more than any diplomat, politician or propagandist can do.

According to Stallknecht \& Frenz (1973), "Literary translations belong not only to the study of the reception of a foreign author in a particular literature, but to the study of literature itself. They provide the best intermediaries between the work of the foreign and native authors, and it is often the form and content of its transmuted, translated form which has the greatest effect upon the native literature, for in this form it is directly assimilable into, and indeed already a part of, the literary tradition." (Stallknecht \& Frenz, 1973, p.88).

A meaningful and successful translation of a literary work can not only arise curiosity of readers but it can often become an integral part of the literature into which it was translated by performing the same cultural functions as the original literary work. Furthermore, a translated literary work informs the reader about the foreign literature and culture and it also develops, enhances and enriches the reader's culture. Translators through translated literary works in addition to influencing and inciting the awakening and deepening of literary ties and relations between nations they can for good measure have an impact on further development of literary kinds and genres and on the intellectual growth and aesthetic and ethical taste of readers.

The importance of literary translation relies not only on the fact that a foreign writer becomes popular because of his/her access to many readers, but because a translated literary work meaningfully enters into a new literary milieu and thereby exerts a fruitful, productive, and creative influence. Without translation, Shakespeare would still remain on an island and none of us would even remember that in our childhood we have read Gulliver's Travels, Robinson Crusoe, Alice in Wonderland, The Last of Mohicans, David Copperfield, The Old and the Sea, etc, translated into our national languages. Without the efforts and contribution of literary translators, Ancient and Classical literature would not have become part of modern literary traditions. Even the Bible would not have had such a huge influence in the vocabulary and stylistic structure of modern languages.

However, though almost all Ernest Hemingway's works were translated into Albanian, it is paradoxical that so far only a few articles, reviews and prefaces on Ernest Hemingway's works in Albanian written. Moroeover, Ernest Hemingway's literary works are not only some of the most translated but the most popular ones in Albanian literature and culture. Therefore, highlighting the

Arab World English Journal for Translation \& Literary Studies 
translation and recpetion of Hemingway's works in Albanian will be the main purpose of this paper.

Namely, the paper will try to shed light on: 1. What is the fortune of Ernest Hemingway's translated works in Albanian? 2. How were Ernest Hemingway's received in Albanian literature and culture? 3. Why did Hemingway become one of the most favorite American writers in Albanian literature and culture? 4. Have Hemingway's works had any impact on Albanian writers?

\section{Literature Review}

Positive literary reception can pave the way to greater reception of a foreign nation's literature. As an example, Byron's and Thomas Moore's popularity in Continental Europe likely contributed to the cult of Shakespeare that developed in numerous Western European nations in the $19^{\text {th }}$ century. Turgenev's reception within the Western literary tradition laid the foundation for the popularity of Tolstoy, Dostoevsky, and Russian literature as a whole. Importantly however, the reception of an author or his works in a literary tradition is not the same as his influence, even though reception might also incite and lead to influence. Thus, while a certain writer may be quite popular in another country, he may not have any significant effect and impact within its literature (Stallknecht\& Frenz, 1973).

However, in order to investigate the reception and eventual impact of a translated work, the critic, researcher or translator must examine both the literary work's macrostructure (e.g., plot, character, and structure) and microelements (e.g., style, dialogue). Unfortunately, "paratexts" (which includes prefaces, afterwords, translator's notes, and reviews) have not closely accompanied Hemingway's work in the Albanian literature and culture. Apart from a handful of journalistic articles, critical treatises, and prefaces, Hemingway's work in Albanian has not been accompanied by a veritable "paratext". This is clearly a gap that needs to be addressed and filled.

Therefore, the focus of this paper will be on reviews, prefaces, afterwards, and articles written by reputable Albanian Hemingway scholars, including Abdullah Karjagdiu, Hasan Mekuli, Ramiz Kelmendi, Fadil Bajra, Pirro Misha, etc. Our paper will also examine articles about Hemingway published in various foreign newspapers, journals and magazines, which were later translated and published in the Albanian prestigious literary journal "Jeta e re".

To achieve these goals this paper will rely mainly on critical, analytical and comparative methods. This is because in order to prove the role, importance and reception of Hemingway's works in Albanian literature and culture, we must evaluate and study reviews, prefaces, afterwards, and articles published in "Jeta e re" about Hemingway and his translated literary works in Albanian. As matter of fact, this paper will rely mainly on principles and methods employed in Comparative literature. According to Wellek and Warren (1948),

Whatever the difficulty into which a conception of universal literary history may run, it is important to think of literature as a totality and to trace the growth and development of literature without regard to lingustic distinctions. The practical result of such thinking will be a general history, especially of the Western tradition. One cannot doubt the continuity 
between Greek and Roman literatures, the Western medieval world, and the main modern litaratures; and, without minimizing the importance of Oriental influences, especially that of the Bible, one must recognize a close unity which includes all Europe, Russia, United States, and the South American literatures. (p.41)

Van Tieghem (1931) is even more clear and concise when he explains that the object of Comparative literature is essentially the study of diverse literatures in their relations with one another. Finally, Stallknecht \& Frenz (1973) provide a definition which best fits with the aims of this paper: "Comparative literature often deals with the relationship of only two countries or two authors of different nationality or one author and another country (e.g., Franco- German literary relations, Poe- Baudelaire, Italy in the works of Goethe)" (p. 10). In our case, the focus is on the relationship between one author, i.e., Ernest Hemingway, and a particular nation and literary tradition, i.e., Albanian literature.

\section{Albanian Journalistic Criticism on Ernest Hemingway Hemingway on Literature}

Albanian journals and magazines have been publishing critiques on Hemingway's works since the 1960s. We will turn our primary focus to one of the most authoritative literary journals in Kosova, "Jeta e re," which published its first Hemingway article in 1960. The first edition of "Jeta e re" (published in 1960) ran a piece titled: "Hemingway's latest interviews on his life and literary creation". (Anonymous, 1960). The anonymous author of this article attempted to pick and choose interesting statements Hemingway gave to various European and American journals and magazines. For example, the piece documented how the correspondent of "Art" Paris newspaper quoted Hemingway as saying, "Writers should read, observe and keep silent" (Anonymous, 1960, p. 151). The piece also provided context on Hemingway's personality, opinions, and values. It relayed how, upon being informed by the "Art" correspondent that he was the fifth most popular author among French readers at the time, Hemingway asked who the most popular author was and was told that it was Dostoyevsky. Hemingway then asked about Shakespeare and the journalist replied that he was the tenth most popular writer in France. Taken aback, Hemingway proclaimed that Shakespeare was greater than Dostoyevsky or any other writer (Anonymous, 1960).

The "Jeta e re" piece also related another interesting anecdote about Hemingway's writing style and creative process. In an interview with the editor of "Week" magazine, Hemingway stated that he had always attempted to describe life as it is and to that end wrote in the everyday language that has come to characterize his "style" (Anonymous, 1960). When asked how long it would take him to write a book, Hemingway stated that it depended on the kind of book. According to him, a good book can take about a year and a half to be written. Hemingway thought that young and inexperienced writers often take writing for granted, thinking that they can never fail; they write with such ease because they simply disregard the readers. However, as soon as they gain experience and begin to pay more attention to readers, they come to understand that writing literature is not as easy as they thought (Anonymous, 1960).

Arab World English Journal for Translation \& Literary Studies 
AWEJ for Translation \& Literary Studies Volume, 5 Number 3. August 2021

The Reception of Ernest Hemingway's Works in Albanian

Karjagdiu, Kryeziu \& Spahiu

\section{Franco hated Hemingway}

In the second issue of "Jeta e re" published in 1961, the following piece was run: Hemingway, persona non-grata in Spain. The paper notes that Hemingway's works, published in American journal "Life," provoked a strong reaction from a number of Spanish newspapers, journals and magazines, some of them even suggesting that he should be expelled from Spain and be banned from entering Spain in future. The controversial work in question was The Dangerous Summer, which explored the rivalry between two well-known bullfighters, Domingo and Ordonez. In 1959, these two bullfighters had accompanied the American writer during his visits in Spain. According to the "Jeta e re" article, Hemingway, as a sensitive observer of human and social events, used these experiences and his short story to criticize Franco regime (Anonymous, 1961).

\section{Was Hemingway an Existentialist?}

In the second issueof "Jeta e re" (1961), the article Is Hemingway and an Existentialist? focuses on selected topics from John Killinger's book, "Hemingway and the Dead Gods." Killenger argues that although Hemingway himself was not an existentialist philosopher, some of his beliefs and opinions accorded with existentialism. For example, Hemingway maintained that each individual has his/her own identity and that this identity can be either independent or part of the crowd (Anonymous, 1961).

The American critic also pointed out that Hemingway's intellectual interests were akin to those of Sartre and Camus; as an example, Hemingway was preoccupied with existentialist concepts like contempt and the Absurd and many of his characters possess similar traits to Sartre and Camus's characters. Killinger also notes differences between Hemingway's opinions and those of the aforesaid two French authors, particularly on topics of social engagement (although only at the outset of his literary career) and love (his ideal heroines usually acquiesce to the protagonist).

\section{Passing of a Giant}

In the second edition of "Jeta e re" published in 1961, another anonymous review was published, titled: On the death of the great American writer Ernest Hemingway. This article focused on Hemingway's life and works and noted the reactions of prominent cultural and political personalities to his death. At the beginning of the review, the author wrote that one of the greatest and most prominent writers had passed away and characterized Hemingway as "the father of the modern generation of American writers" (Anonymous, 1961, p. 550). This was more or less how most American newspapers and journals reacted to the death of Hemingway. After providing relevant information about his life, the article pointed out that Hemingway's first work, Three Stories and Ten Letters (a translating error was made here; instead of "letters, the word "poetry" should have been used), was not very well received by readers. It was only his first novel The Sun Also Rises (published in 1926) that brought him his first great success, while "A Farewell to Arms" further established his literary reputation. In the "Jeta e re" review, it was also noted that Hemingway was a humanist and antifascist; he had condemned Italian fascist politics in Ethiopia from 1935 and he was a war correspondent who supported the Republicans in the Spanish Civil War, during which he was inspired to write For Whom the Bells Tolls. According to the review author, that novel, "with its originality and conceptions, conquered the world for more than ten 
years". It must be noted that there are also slight errors in the review, e.g., the author refers to some Hemingway short stories and novellas (such as The Snows of Kilimanjaro) as "novels" (Anonymous, 1961).

This article also reminded readers that Hemingway was awarded the 1954 Nobel Prize for Literature for his novella The Old Man and the Sea, which was translated into various languages and made into several films. The review also noted the reactions and opinions of distinguished writers and personalities on his suicide. Tennessee Williams said that Hemingway loved life and literature, and that he was capable of saying things that were seemingly impossible to express. The renowned writer John Priestley emphasized that Hemingway had influenced many writers worldwide. According to Priestley, "he was a subtle writer" who was capable of relaying a message in a simple, lucid way (a virtue in the modern Anglo-American literary tradition) (Anonymous, 1961).

Well-known American novelist William Faulkner also had a high opinion of Hemingway. The author of the review quotes Faulkner as saying, "He was as great as the books he left behind. He was my great friend. He dedicated his entire life to the writing craft" (Anonymous, 1961, p.551). The review also notes that Scribner, Hemingway's publisher, declared that he was a great writer and will remain great in future since "his books were special and will live for centuries ahead." (Anonymous, 1961, p. 551). François Mauriac declared that this was a great loss for literature and the American novel, in particular; and the great Italian novelist Alberto Moravia said, "Hemingway's loss left America without one of the two best American writers. Faulkner was the second" (Anonymous, 1961, p. 552). Last but not least, President John Kennedy asserted that Hemingway influenced the ways of thinking of readers both in America and all over the world, which made him a world citizen. Kennedy concluded that Hemingway "ended his life, the way he began it, at the heart of America to which he brought fame and from which he immersed the power for his art" (Anonymous, 1961, p. 553)

Has the legend on Hemingway been forgotten?

The sixth edition of "Jeta e re", published in 1965, ran an article by Abdullah Karjagdiu titled: Has the legend on Hemingway been forgotten? The article wrote that even five years before Hemingway passed, his wife had "to defend the legend about him". She had put in a request with the New York Supreme Court to ban the publication of A.E. Houchner's biography, Papa Hemingway. The book chronicled sometimes-salacious episodes such as his romantic escapades, passion for hunting, disappointments, and suicide attempts.Houchner, as Ernest Hemingway's friend, was in a position to relay events from Hemingway's childhood, the Paris literary scene he was part of in the twenties, his early years as a writer, etc. Houchner recorded all these events and wanted to recount the biographical details that undergirded Hemingway's fiction. Although Mrs. Hemingway had requested from the NY Court that Houchner's book not be published, the chances of the court granting her request were slim and it was believed that the biography would become a bestseller (Karjagdiu, 1965)

Arab World English Journal for Translation \& Literary Studies 
AWEJ for Translation \& Literary Studies Volume, 5 Number 3. August 2021

The Reception of Ernest Hemingway's Works in Albanian

Karjagdiu, Kryeziu \& Spahiu

\section{Albanian Literary Criticism on Ernest Hemingway}

Hemingway and the readers

One of the first literary critiques written in Albanian about Hemingway's life and works was published at the end of the Albanian translation of his novella The Old Man and the Sea, which was translated by Ramiz Kelmendi and Masar Murtezai in 1957. Although the author of the critique is anonymous, the original version was most likely written in another language and translated into Albanian for this publication. The critical review focuses on Hemingway's popularity among his many readers and characterizes him as not only a world citizen (cosmopolitan), but also an internationally known writer, since his books can be found all over the globe (Anonymous, 1965).It writes, "his works are read by pupils, civil servants, philosophers, housewives, travellers, retired, workers, semi-literate, literate, educated, snobs, his admirers, indifferent scholars, etc"(Anonymous, 1965, p. 178). The critique also examines different motivations for reading Hemingway's works: to be entertained, forget about everyday hardships, better understand human psychology, or learn about the philosophy behind his works. The critique also notes that many readers think that Hemingway is a good narrator, but tends to leave out important details to keep the reader engaged (Anonymous, 1965). According to the critique, "the first, the second, the third, and the tenth kind of reader are disappointed sometimes with the writer. As Hemingway, this great fisherman, is as strange as the sea, he can impress, cheat and deceit" (Anonymous, 1965, p. 179).

The second part of the critique concerns Hemingway's life. It references many events and details from his youth; family life; career as a journalist/reporter; participation in WWI, WWII, and the Spanish Civil War; hobbies and voyages; life in Paris; and his life after achieving widespread acclaim (Anonymous, 1965). The next sectiontitled Hemingway's Books is a chronological list of Hemingway's works and their translation into Albanian. The next part titled Hemingway's Minimalism focuses on Hemingway's aversion towards depicting intricate events and dramas. According to the critique, Hemingway made significant innovations when it came to narrative and the composition of literary works, oftentimes infringing upon the rules of the traditional plot and classical prose. The critique said that Hemingway wrote simple, lucid, and concise sentences in order to avoid tiring and boring his readers. He let his characters develop their dialogue spontaneously, so as to make the artistic life true to real life (Anonymous, 1965).

The last part of the critique titled Hemingway is not really simple points out that although Hemingway was very popular and acclaimed, his writing is not as simple as it might seem. His simplicity, according to the critique, is as elaborate, planned and meticulous as the simplicity of a telegram. His style is clear and short; the words used in his sentences allude to ideas that are not stated directly. Thus, attentive, thoughtful readers as well as an inattentive, non-serious audience can enjoy his works (Anonymous, 1965). In his early short stories, Hemingway included sketches that depicted short, shocking social events from everyday life, which did not have any organic relation to the plot, but were placed at the heart of the story to attract the attention of the readers and deepen their understanding of character and the story's theme. For example, before Nick Adams is portrayed fishing trout, Hemingway included a sketch in which the character remembered killing the first enemy soldiers; he thus implied that the character's conscience was not as clear as it appeared to be (Anonymous, 1965).

Arab World English Journal for Translation \& Literary Studies 
AWEJ for Translation \& Literary Studies Volume, 5 Number 3. August 2021

The Reception of Ernest Hemingway's Works in Albanian

Karjagdiu, Kryeziu \& Spahiu

\section{Hemingway- Gauge of Morale}

In the fourth edition of "Jeta e re" published in 1961, the Albanian translation of Hemingway's short story Soldier's Home(translated by Tajar Hatipi) was published along with a short passage written by Edmund Wilson. Though it does not say who translated the critic's note, we believe that it was translated from Serbian.

Edmund Wilson is one of the most acclaimed modern American literary critics who lived and worked between WWI and second half of the 20th century. As a writer, he is known for his poems, novels, short stories, plays, but most of all for his literary criticism, especially in Axel's Castle, Classics and Commercialists, and The Shores of Light. In the passage translated in "Jeta e re", Wilson analyses some of the Hemingway's short stories and tries to shed light on Hemingway as a social critic(Wilson, 1941 as cited in "Jeta e re", 1961).He focuses on Old Man at the Bridge, in which the reader is presented with a pale-faced old man whoever showed interest in politics, but was forced to leave two goats, a cat, his dear friends, and everything else because of attacks by the Spanish fascist army. This story, according to Wilson, resembles the elegance and acuteness of Kamot and Goya's artistic works (Wilson, 1941 as cited in "Jeta e re", 1961).The story is simple, but for Wilson, Hemingway succeeds in depicting city life, the social atmosphere of the clergy and working class, and the life of weary bullfighters.

Analysing the antagonism between men and women (in particular, women's struggle to dominate men), Wilson asserts that Hemingway treated this subject from his earlier works too. He reminds us that in The Doctor and the Doctor's Wife, Nick Adams preferred to hunt squirrels with his dad than to listen to his mother's preaching. In Cross Country Snow, according to Wilson, the character regrets having to bid farewell to his friends and go back to America, where his wife is pregnant and waiting for him. Likewise, a young lover in Hills Like White Elephants, pressures his loved one to abort their child against her will. In A Canary for One, Wilson says that Hemingway examines the case of a woman separated from her husband. The peasant in the short story $A n$ Alpine Idyll insults his wife's corpse, while Brett in The Sun Also Rises, according to Wilson, is a symbol of a destructive power. She would make a better wife had she married Jake, but he was isolated from her because of his impotence. Jake Barnes's misfortune in A Farewell to Arms (i.e., having a stillborn child, the death of a loved one) frees him from "obligations" towards his wife, according to the critic (Wilson, 1941 as cited in "Jeta e re", 1961). Furthermore, Wilson maintains that Nick Adams's best experiences with women were the ones of his youth with young Indian ladies, who easily accepted subjugation to men and did not attempt to change men's behaviour, and so were easily disposable. In The Fifth Column, Mr. Philip avoids being influenced and discouraged, brutally gets rid of Dorothy, and thereafter is able to join the communist movement. Wilson concludes that Jake Barnes in The Sun Also Rises is saved from physical injury, which enables him to take revenge on naive Brett. Harry Morgan is portrayed as a man who cannot satisfy his wife, and thus has to leave her and face death (Wilson, 1941 as cited in "Jeta e re", 1961). Wilson believes this instinct to subdue comes from men's fear of women's desire to control them. In The Short and Happy Life of Francis Macomber, the man saves his soul at the last moment, only to have his unfaithful and foolish wife kill him because she does not want him to have dignity.

Arab World English Journal for Translation \& Literary Studies 
In the end, Wilson concludes that many politicians were wrong when they accused Hemingway of being indifferent towards the society and times in which he lived. On the contrary, Hemingway reacted against suppression and moral persecution in human relations and directly criticized contemporary society. When it comes to politics and ethics, everything depends on bravery and individual strength for Hemingway - bravery and strength are even more important than physical size (e.g., the courageous bullfighter that puts his life at risk is braver than any other man.)(Wilson, 1941 and cited in "Jeta e re", 1961).Thus, although Hemingway's main focus is on fights and races in which his characters are almost always physically crushed, they consistently end up moral winners.

\section{Ernest Hemingway-Life and Works}

"Jeta e re" no. 1 (1974) published a rather long review (it consists of four parts) by Hasan Mekuli. Mekuli focuses on three of Hemingway's works: his collection of short stories In Our Time, his novel The Sun Also Rises, and A Farewell to Arms. At the outset, Mekuli surveys American literature from the 1920s till present, writing, "the most characteristic generation of American writers are the so-called writers of the lost generation" (Mekuli, 1974, p.115). Mekuli explains that the term "lost generation" was first used by Gertrude Stein to describe intellectuals, writers, and artists who were traumatized after their participation in WWI, escaped the gloomy post-war atmosphere in the U.S., and resettled in Paris. Hemingway was seen as a member of this lost generation. Mekuli also briefly explains Hemingway's creative process: Hemingway knew neither how became to be inspired - sometimes the idea simply came to him while he was working — and nor how his stories would end (Mekuli, 1974)

According to Mekuli, most of the themes and events in In Our Time are related to episodes from the author's life. Nick Adams is the young Hemingway; Nick's father, a doctor, is Hemingway's father, who was also a doctor; the character lives in Chicago or Michigan, where Hemingway spent his boyhood. However, per Mekuli, these real-life episodes were artistically transposed into sketches that Mekuli calls "poetry in prose". Similarly, the author's personality was represented in characters with different names, but with similar behaviours, attitudes, and opinions to the real Hemingway (Mekuli, 1974). Commenting on the short story The End of Something, Mekuli says that this short story is about Nick, who falls out of love and becomes depressed; he is not interested in Marge anymore and ends up leaving her forever. Regarding The Three Day Blow, Mekuli writes that the characters spend most of their time drinking, womanizing, playing sports, discussing literature and killing time. Mekuli was of the opinion that The Killer, Ten Indians, The Capital of the World, and The Short and Happy Life of Francis Macomber are mainly concerned with death, since most of the characters are disappointed, suffering, alienated, in conflict with their families and surroundings, and unable to find their way out of the labyrinth of life (Mekuli, 1974). Doubtless, many of these plot and character elements were derived from events and people in Hemingway's own life.

In the third part of the review, Mekuli analyzes The Sun Also Rises, with allowed Hemingway to enter "American Literature through the big door," according to Philip Young. This novel, in which events are narrated in the first person by protagonist Jack Barnes, is about mundane society and the lost generation that wandered Paris searching for consolation in alcohol, empty 
dialogues, and women. Per Mekuli, Jack epitomizes the lost generation, while Robert Cohnis the antithesis of Barnes. Mekuli believes that Barnes is the most attractive character because of his attitude towards creative work and ultimately tragic position (his genitals were damaged), which makes him different from the other characters. Yet even Barnes drowns his sorrows in alcohol; he is in love with the beautiful and adventurous Brett Ashley, but war wounds have disabled him from having a normal romantic relationship. Even in such a state, Barnes does his utmost to preserve friendships and he seeks peace in nature and art. On the other hand, Robert Cohn is a charming, but mediocre character that, according to Mekuli, does not have a conscience or consideration towards others. Mekuli also gives a brief overview of the other characters-Lady Brett Ashley, Bill Gorton, Mike Campbell, Count Mippipopolous, etc.- -and argues that each is emptier than the last: they've lost their faith in life and are wandering purposelessly, having fun, and killing time (Mekuli, 1974).

In the fourth part of the review, Mekuli focuses on A Farewell to Arms, an anti-war novel that severely criticizes meaningless militarization and bloodshed. The critic quotes Pasini, who tells Henry, "We are governed by a class of fools, who don't and will never understand a damn thing. That's why we are having a war. Is suits them as they earn money." However, as the critic rightly noticed, Hemingway interweaves themes of love into this rebuke of war, creating a touching and subtle romantic novel. "War as a tragic end of a love relationship between the American gentlemen Henry and the British nurse Catherine Barkley," says Mekuli (1974), "coalesces with their love and kindness, or love as a ray of hope, obscured and extinguished by the gloomy shadow of the war and the tragedy that it causes." (p. 116). Mekuli thinks that the novel consists of two main stories: the first one is about cruel, merciless war and the second one is about love, dreams of happiness, and human tragedy. Mekuli concludes that love gives Henry the strength to cope with suffering and danger, defect from war, and evade execution; however, just when he thinks he's the happiest man on earth (i.e., while waiting for Katherine to deliver the baby), Katherine and the baby die.

\section{A Man in a Stormy Fate}

In "Jeta e re" no. 4 HasanMekuli (1978) wrote A man in a stormy fate, in which he explores The Old Man and the Sea. In this critique, Mekuli reiterates that this work too has autobiographical elements and adds that he thinks that it sublimates Hemingway's aesthetic, ethics and stylistic traits, "In this novel, in a natural and consequent way, we come across with the same short, clearcut and lucid sentences, with sensible and frequent descriptions, with the same witty and fluent dialogues, with the colloquial and always genial language..." (Mekuli, 1974, p. 601).

Mekuli argues that The Old Man and the Seais a poem in prose, which relates the story of Santiago, a Cuban fisherman, who after failing to catch a fish for months, goes off to sea alone to catch a huge fish. The old man does everything in his power to protect his catch, including fighting sharks, but remains only with the skeleton of the fish at the end. Yet, through this ordeal, Santiago regains his self-confidence and proves that an individual can never be defeated as long as he/she keeps fighting. According to Mekuli (1974) the main theme of the novella is the struggle of the individual to find meaning inexistence, to use every last atom of his creative energy, positive ambition and endless desire - to lead an active life. Santiago, the protagonist, confirms 
Hemingway's belief that man can face tragedies, yet not be wiped out as long as he never accepts defeat (Mekuli, 1974). Mekuli believes that this novel has only one character and that society does not play any particular part in it; the individual's attitude towards the tempest of life is the author's main preoccupation (Mekuli, 1974).

Suffices it to say that Mekuli expresses an interesting opinion on the destiny of Hemingway's work translated in Albanian. He writes, "For some time now Hemingway enjoys a huge authority as one of the dearest and most read and admired writers since his mindset, sentence, observance and culture in general have become part of our culture in a very characteristic way, no doubt as a very pure aesthetic value" (p. 605). According to Mekuli, two of Hemingway's most appreciated works among Albanian readers are "For Whom the Bell Tolls" and "The Old Man and the Sea". Regarding the latter, Mekuli praises Ismail Kadare's Albanian translation,

perhaps because this is where the two lyrical thinkers have met, two poets inspired by creative optimism and two authors, who attract us with the beauty of their art, with peculiarities of their thoughts and their full dedication to literary work (p. 606).

\section{A Few Words on Hemingway's Poetry}

In "Jeta e re" no. 4, Fadil Bajra (1988) published a short article on the Albanian translation of Hemingway's collection of poems 88 Poems, which were published posthumously in 1979. He says that only 25 of them were published while he was alive, whereas the others were published after his death. Bajra believes, as many critics do, that in order to understand Hemingway's works, it is essential to first know his life. He concurs with some American critics that Hemingway inserted autobiographical elements into almost all his works (Bajra, 1988).

Upon publication of Hemingway's Three Stories and Ten Poems, the well-known critic Wilson (1961) wrote, "Hemingway's poems are not so important, but his prose is excellent". Hemingway divided his collection of poems "88 Poems" into four cycles, which were based on his biography. According to Bajra (1988), in the first cycle, Hemingway imitated Kipling's verse; the second cycle consisted of love and satirical poems against war and literary critics; in the third cycle, Hemingway included descriptive and satirical poems; and the fourth cycle contained reflexive and meditative poems. Of his poems written during the 1930s, Bajra (1988) examines Advise to a son, a didactic poem in which the narrator advises his son to never trust a white man, to not kill Jews, not volunteer to go to the army, not get married too many times, not reject good things in life, not trust war, honour his heritage, not blackmail people and not get married to bitches.

Hemingway tried his hand at poetry with the help of the distinguished modern poet Ezra Pound. Pound believed that Hemingway had the talent to write poetry, but that he excelled at prose. Hemingway was influenced by Gertrude Stein, especially when he wrote his long poem The Soul of Spain published by McAlmon and Bird. Hemingway had mainly published his poems in elitist literary journals; at the same time, some journals refused to publish his poems because he used rude language-Hemingway published them as illegal pamphlets (Bajra, 1988). As Bajra (1988) 
notes, it appears that Hemingway wrote most of poems hastily; some were later revised, while others were in manuscript.

\section{The Best Thing in Life-Genuine Prose}

In the preface to the Albanian translation of a collection of short stories and other works titled Snows of Kilimangaro, short stories, novels and other works (published in 1990 in Tirana), Misha (1990) details Hemingway's biography, explores his writing style, and finally briefly discusses his best short stories. Suffice it to mention that in the first part of his preface, Misha asserts that Hemingway once had said to a friend that the best way to become a writer is to have a difficult and unhappy childhood. Hemingway, notes our critic, meets the criterion.

At the same time, Misha is confident that all of Hemingway's works, starting from the Nick Adams short stories and going to his last novel The Old Man and the Sea, are a sort of fictionalized autobiography. Emphasizing the consequences of Hemingway's real-life adventures, wounds and traumas, Misha was inclined to believe that war made Hemingway the most prominent representative and spokesman of the post-WWI ethos, when all ethical and traditional values were put to question. Aside from the traumas experienced by many in his generation during WWI, there was a brutal, internal clash between Hemingway's youthful dreams and illusions and the merciless, cruel reality of war and death. That generation, explains Misha (1990), became "a lost generation" (p.2)

Misha went on to analyse and discuss Hemingway's works, claiming that despite a great response to his short story collection In Our Time, the work did not bring him much popularity. It is only after the publication of The Sun Also Rises, one of the novels most representative of the lost generation "and Hemingway's masterpiece," that his reputation as a great modern novelist was established. This novel follows a group of disillusioned young people after the war; they spend their time fishing, drinking in cafés, and having adventures and endless discussions. Nevertheless, underlying this apparently hedonistic life is "their attempt to at least preserve something from the ruins", which is why "they struggle to maintain their welfare, sincerity and love so as to give the minimum logic to their lives"(Misha, 1990, p. 3).

By the end of 1920s, Hemingway had become very popular and famous. Misha believes that Hemingway had become an attractive subject for sensationalist journalists. He notes that Hemingway was sometimes disappointed and ironic, sometimes lonely and gloomy, and sometimes unrestrained and eager to face dangers. This was a time when Hemingway preferred participating in war than being a war reporter. Indeed, two main values that dominate the Hemingway's philosophy are courage and manhood, with Hemingway's quintessential hero being a stoic, dignified man who faces death and conquers fear. Misha maintains that Hemingway's novel To Have and Have Not(1937) is a paragon of this attitude and outlook. Harry Morgan, the protagonist of the novel, not only epitomizes the American individualism, but is also a fearless man who, 
is ready to stand up and fight to protect his way of living, but at the moment of death he winds up as a loner, deserted and punished..." Although it was not very well received, this novel marks the end of Hemingway's belief in individualism for Misha. (p.3)

The critic also has a high opinion of Hemingway's novel For Whom the Bell Tolls because it "is one of the most important of Hemingway's works, a complex novel, with a tragically, stoic and typical hero for Hemingway's philosophy, a novel on war, a shocking epopee and an antique tragedy" (Misha, 1990, p. 5). However, according to the critic, Hemingway's work is a reflection of the man himself. During WWII, Hemingway was considered an active writer in the world press and his name was often mentioned in the fight against fascism. Back then, he worked as a reporter and supported the cause of democratic forces in France, where he participated in the landing of Allied Forces at Normandy and the liberation of Paris. However, he didn't write literature during that period-he did not have time. Only in 1950, as Misha notes, did Hemingway publish his next fictional work, Across the River and into the Trees, which was not very well received by some critics. But his next work, The Old Man and the Sea, which the critic considers Hemingway's swan song, is believed to be among his best and it also revived his popularity. When he was awarded, the Nobel Prise for Literature in 1954, Hemingway became "one of the leading and most influential writers in world literature. He made a huge step forward by increasing his image as a sportsman and a man of action, which he created for himself" (Misha, 1990, p. 14). Unfortunately, soon after that, his health deteriorated.

Misha is right in praising Hemingway's powerful, laconic style, which is also vigorous and sounds like real life speech. Misha considers Hemingway's dialogue spontaneous, challenging, ordinary, dramatic, fluent, and free of needless intricacies and fictionalization. He also hated complicated, hackneyed words. For Hemingway, all modern American literature derived from The Adventures of Huckleberry Finn. Hemingway thus demarcated the period of American literature that he thought stood in need of fresh blood in order to capture the spoken language of the people (Misha, 1990)

Misha also comments on Hemingway's short story collections. According to Hemingway, as written in Death in the Afternoon, a novelist can omit explicitly mentioning things that he thinks the reader can ascertain by him/herself; in some cases, the writer can achieve a greater artistic effect than if he directly portrayed those same details. This is Hemingway's famous iceberg principle (Misha, 1990)More generally, Misha is convinced that Hemingway wants to depict the truth about the life and reality in a way "that would be integrated in the reader's conscience, in the way that would be the same with his/her real life experience"(Misha, 1990, p. 19).In other words, if Hemingway's aim were achieved, the reader would follow the words, behaviours, and thoughts of a novel's characters and react to plot events as if they were part of real life.

Another novel that attracted Misha's attention is Green Hills of Africa. According to the Albanian critic, this work introspectively examines the writer's own morality and purpose in life; the reader is thus forced to consider life of the artist and his fragility when facing difficulties and temptation. In the story, Harry is underestimated by his wealthy wife and just before he dies, he reflects on his life and decides to not allow anything to hinder him in accomplishing his fundamental purpose. But just when he decides to do so, he dies (Misha, 1990). 
In other short stories, Hemingway returns to the world of his childhood and adolescence with some displeasure and soreness. These feelings, according to Misha, emerge clearly in Murderer, where the character rejects evil, protests, is indignant, but is aware of his ultimate hopelessness and feebleness. Touching upon some other Hemingway's novels, the Albanian critic concludes that A Clean Well-Lighted Place is Hemingway's most interesting and popular short story; it depicts "a realistic background, where he unfolds some self-evident or presumed dramas (events), and where there are two key words - dignity and "nada" (oblivion)".

In The Undefeated, Hemingway depicts the dignity of an old bullfighter who preserves his pride despite failure. In his short story The Capital of the World, the author explores the dreams of a village boy who moves to town; with this story, "Hemingway depicts the death of an innocent man, who did not have time to live his life"(Misha, 1990, p. 20). At the end of this critical preface, the critic reminds Albanian readers that they were first introduced to Hemingway in 1950s; in the1960s, three more of his works were translated into Albanian. Later in Kosova, the Albanian translation of For Whom the Bell Tolls was published; however, "there are still quite some works that need to be translated", and it must be noted that by collecting part of Hemingway's short stories, Misha brought at least part of Hemingway's short prose into Albanian literature.

\section{A Spiritual Feast for Albanian Readers}

In the preface to a translated collection of Hemingway's short stories titled Today is Friday (translated by Artjan Guskiqi in 1996), the author says that the selection was made based on theme, i.e., war. "Friday is the day when Christ was crucified," the author of the preface writes, "it is the day that awaits thousands of soldiers, who were thrown in the slaying and bloody war, where man fights against man". In this short story collection, the crucifixion of Christ is portrayed as a grave act that encourages the solidarity of Roman soldiers (Anonymous, 1996). The anonymous author of the preface claims that war and its tragic consequences were an inseparable part of Hemingway's life, and thus became "raw material" for his works. Rather than being completely bleak, Hemingway's message is quite humanistic, though his humanism can be harsh and profoundly realistic. In Hemingway's hands, war and its horrendous consequences become "meaningful symbols, which [are] very educational for the future generations" (Anonymous, 1996, p. 2).

In this short preface, it is also noted that the translation of works of distinguished writers like Hemingway "is always a spiritual feast" for Albanian readers. The author emphasizes that Hemingway is one of the most famous American writers and that many of his main novels and short stories have already entered Albanian libraries. The anonymous author ends the preface with the following remark, "A new translated work of Hemingway's work in Albanian becomes a feast for the reader" (Anonymous, 1996, p. 3).

\section{Discussion}

In this paper, the destiny of the Hemingway's work in Albanian literature and culture has been presented, discussed and analyzed. This was done by focusing not just on diverse reserch books and studies on Hemingway, but more on journalistic and literary reviews and other writings published in the Albanian literary journal "Jeta e re". Therefore, the paper focused on those few 
reviews, prefaces, afterwards, and articles written by reputable Albanian Hemingway scholars, including Abdullah Karjagdiu, Hasan Mekuli, Ramiz Kelmendi, Fadil Bajra, Pirro Misha, etc. However, in addition, the paper examined articles about Hemingway published in various foreign newspapers, journals and magazines, which were later translated and published in the Albanian prestigious literary journal "Jeta e re".

According to Ghasemnejad \&Anushiravani (2018),

Reception of a literary figure in a country other than the writer's home country is crucial to the overall literary enquiry of that country. It is a fresh way of seeing a given literature through the lens of external and international literature. Investigation of literary fortune of a writer in a country other than his/her own is one of the popular and enlightening fields of research. (p. 29)

Hence, after many disussions, comparisons, explorations and evaluations of Hemingway's translated literary works in Albanian and those few prefaces, reviews and articles written in Albanian on Hemingway, it is possible to ascertain that the reception of Hemingway's literary works in Albanian literature and culture, had begun more then half a century ago, that his works, despite the lack of serious response of the literary criticism in Albanian, has been welcomed warmly, excepted with curiosity and spread out spontaneously. In brief, his reception has been successful. Namely, Hemingway's works and masterpieces began to be translated into Albanian by the end of the 1950s (specificly in 1957), even before the Albanian language was standardized. Thus, reception of Hemingway's translated works within Albanian literature and culture began in the second half of the 20th century, and it continued to grow in 1960s before reaching its peak in the 1990s. The first literary mediators, who made it possible for Hemingway's works to "cross" the linguistic boundary, were the Albanian translators. Among were some of the most talented, experienced and well-known intellectuals, scholars, writers and translators in the Albanianspeaking world, including: Masar Murtezai, Ramiz Kelmendi, Vedat Kokona, Alqi Kristo, Ismail Kadare, Sylejman Drini, Piro Misha, Artjan Guskiqi, Juliana Kurti, Sazan Gjomena, Pavli Qesku, etc..

Moreover, his translated works were published and republished frequently in Albanian, while the artistic and ethic values as well as the code hero of his characters have expanded both the horizon of expectation and aesthetic taste of Albanian readers. At the same time Hemingway's works in Albanian have accompanied the growth of modern Albanian fiction in a particular atmosphere, whereas the mere fact that even after half a century, during the first two decedes of the 21 st century, the interest for his work has been steadily growing, confirms that Hemingway has become one of the most favorite authors of almost all kinds of Albanian readers. Finally, it is also worthwhile noting that most of these conclusions are in concordance and harmony with the thoughts, opinions and assessments of the majority of researchers and scholars of Hemingway's works

\section{Conclusion}

An impactful and successful translation of a literary work not only sparks the curiosity of readers, but also allows the work to perform the same functions as in its original language and 
become an integral part of a new culture and literary tradition. Furthermore, a translated literary work informs new readers about foreign cultures and develops, enhances and enriches the readers' world views. In addition to influencing and deepening literary ties and relations between nations, translated literary works often further influence, develop and sophisticate the literary genres and aesthetic tastes of the receiving culture, and even catalyze large-scale cultural growth.

Therefore, the destiny and reception of Ernest Hemingway in Albanian literature is of singular scholarly importance given that his translated literary works were contemporaneous with the development of modern, 20th century Albanian prose. Albanian journals and magazines, in particular Kosova's "Jeta e Re," have been publishing articles and critiques on Hemingway's works since the1960s. Similarly, translated versions of his masterpieces and popular stories have been published frequently throughout Albania and Kosovo, and the artistic and ethical values of his works have undoubtedly broadened the perspectives of Albanian readers. Furthermore, Ernest Hemigway has even influenced the distinguished Albanian writer Pepro Marko to write his novel "Hasta la vista" which was inspired by the the same event and which explores the same theme, the Spanish Civil War.Lastly, Hemingway's works have accompanied and inspired the growth of modern Albanian fiction itself and public interest in his work has been steadily growing-indeed, Hemingway, along with Mark Twain, Jack London, Theodore Dreiser, Willaim Faulkner, has become one of the most popular authors among Albanian readers. Hence, by examining prefaces, reviews, and critiques to Hemingway's translated work, this paper fills a lacuna and illuminates Hemingway's reception in Albanian literature and culture as a whole.

\section{About the Authors:}

Lirak Karjagdiu is an associate professor of English, American and Comparative literature at the University of Prishtina. Taught English language and literature in Kosovo and abroad. Participated in conferences and seminars. Published a lot of books, monographs, research papers, articles and book reviews in Albanian and English. ORCIDiD: https://orcid.org/0000-0001-8372-2372

Naim Kryeziu in 2012, under the scientific supervision of the Austrian academic Karl Wagner, he defended his Ph.D dissertation entitled "Heinrich Heine's literary work and its reception in Albanian". He immidiately was appointed as an assistant professor at the University of Prishtina, in the Department of German Language and Literature where he teaches German language. He is a well known literary translator in Kosovo and Switzerland.ORCIDiD:https://orcid.org/0000$\underline{0002-1501-6617}$

Isa Spahiu is an associate professor of English language at the University of Tetova. Taught English language in North Macedonia, Kosovo and abroad. Participated in conferences and seminars. Published a lot research papers, articles, books and book reviews in Albanian and English languages. ORCIDiD: https://orcid.org/0000-0002-6362-9856

\section{References}

Abrams, M.H. (1970). A Glossary of Literary Terms. New York: Halt Rinehart Winston. Anonymous, (1960). Hemingueji per letersine.[Hemingway's latest interviews on his life and literary creation- our translation]. In "Jeta e re" no. 1. Prishtinë: 151-155. 
AWEJ for Translation \& Literary Studies Volume, 5 Number 3. August 2021

The Reception of Ernest Hemingway's Works in Albanian

Karjagdiu, Kryeziu \& Spahiu

Anonymous, (1961a). Hemingueji, person non-grata. [Hemingway, persona non-grata in Spainour translation]. In "Jeta e re" no. 2. Prishtinë: 185- 188.

Anonymous, (1961b). A ishte Hemingueji ekzistencialist? [Was Hemingway and Existentialist? our translation]. In "Jeta e re" no. 2. Prishtinë: 195- 202.

Anonymous, (1961c). Mbi vdekjen e autorit të madh amerikanErnest Heminguej [On the death of the great American writer Ernest Hemingway- our translation]. In "Jeta e re" no. 2. Prishtinë: 550- 555.

Anonymous (1965). Jeta dhe vepra e Ernest Heminguejit [Ernest Hemingay's lie and works- our translation]. Cited in Ernest Hemingway (1957). The Old Man and the Sea. Translated by Masar Murtezai dhe Ramiz Kelmendi. Prishtinë: Publishing House "Milladin Popoviq".

Anonymous (1996). Hemingway, E.Preface toToday is Friday (A. Guskiqi, trans.). Tirana: Publishing House "TOENA."

Bajra, F.(1988).Njëmendësia e jashtëzakonshme. Shënimi për autorin dhe përkthimi i poezive. [Extraordinary reality. A few words on Hemingway's poetry- our translation] In "Jeta e re", no. 4. Prishtinë:. 439 - 456.

Beach, J. (1972) American Fiction 1920 - 1940. New York: Russell \& Russell

Brooks, C.,\& Warren P.W. (1953). Understanding Fiction. New York: Appleton - Century-Crafts, Inc.

Chase, R. (1957). The American Novel and Its Tradition. New York: Doubleday.

Ghasemnejad, A., \& Anushiravani, A. (2018).The Early Literary Reception of Ernest Hemingway in Iran. International Journal of Comparative Literature \& Translation Studies, 29-35. http://dx.doi.org/10.7575/aiac.ijclts.v.6n.1.

Hart, J. (1965).The Oxford Companion to American Literature. New York: Oxford University Press.

Harry, L. (1951). Observations on the Style of E. Hemingway. The Kenyon Review,581-609. https://www.jstor.org/stable/26278613. Ohio: Kenyon College.

High, P. (1994). An Outline of American Literature Longman. London and New York.

Karjagdiu,A.(1965).A është harruar legjenda mbi Heminguejin? [Has the legend on Hemingway been forgotten?- our translation]. Jeta e re,(6), 172-175.

Mekuli, H. (1974). Analizë e veprave Në kohën tonë, Dhe lind dielli dhe Lamtumirë armë. [Critical analysis of Ernest Hemingway's "In Our Time," "The Sun Also Rises," and" A Farewell to Arms, " - our translation]. Jeta e re, (1), 207-2019.

Mekuli, H. (1978).Njeriu në stuhinë e fatit. [A man in a stormy fate - our translation].Jeta e re,(4),601-608.

Mc Michael, G. et al. (1985). Concise Anthology of American Literature. London, New York: McMillan Publishing Company.

Misha, P. (1990)Parathënie në veprën e Ernest Heminguejit "Dëborat e Kilimanxharos, tregime, novela, etj. [Preface in Ernest Hemingway's Snows of Kilimangaro] (P. Misha, trans.). Tirana: Publishing House "Naim Frasheri."

Shipley, T. J. (1969). A Dictionary of World Literature. New Jersey: Littlefield, Adams and Co., Totowa, New Jersey.

Stallknetcht, N., \& Frenz, H. (1973). Comparative Literature. Method and Perspective ( ${ }^{\text {nd }}$ rev, ed.). London and Amsterdam: Southern Illinois University Press.

Arab World English Journal for Translation \& Literary Studies 
AWEJ for Translation \& Literary Studies Volume, 5 Number 3. August 2021

The Reception of Ernest Hemingway's Works in Albanian

Karjagdiu, Kryeziu \& Spahiu

Vanspanckeren, K. (1995). Outline of American Literature, USIA. Published by United States Department State.

Wellek, R., \& Warren, A. (1948). Theory of Literature. New York: Harcourt, Brace and Company

Wilson, E. (1978). The Wound and the Bow. New York: Farrar, Straus and Cudaby as cited in "Jeta e re" no. 4. (1961), Tajar Hatipi. Heminguej - masa e moralit (In English: Hemingway: Gauge of Morale): 498-502. Prishtina. 